\title{
Aldersgrense for legers autorisasjon og lisens
}

\begin{abstract}
Sammendrag
Bakgrunn. Med legeloven av 1980 ble det innført en bestemmelse om at autorisasjon som lege opphører ved fylte 75 år, med mulighet for fortsatt begrenset lisens etter søknad. En slik bestemmelse er internasjonalt nokså uvanlig. Vi ønsket å se nærmere på hvilken oppfatning leger i forskjellige aldre har om dette.
\end{abstract}

Materiale og metode. Artikkelen er basert på to spørreskjemaundersøkelser, én til 1400 yrkesaktive leger i 2006 og én til 900 pensjonerte leger i 2007.

Resultater. $69 \%$ (969/1 400) av de yrkesaktive og $92 \%$ (829/900) av legepensjonistene svarte. $80 \%$ (772/969) av de yrkesaktive og $34 \%$ (284/829) av de pensjonerte legene var enig i bestemmelsen om at leger over 75 år må fornye sin lisens. $25 \%$ (97/389) av respondentene over 74 år hadde lisens på undersøkelsestidspunktet.

Fortolkning. De fleste leger under 70 år godtar aldersbestemmelsen, mens misnøyen med den øker med økende alder.

\author{
Olaf Gjerløw Aasland \\ olaf.aasland@legeforeningen.no \\ Legeforeningens forskningsinstitutt \\ Postboks 1152 Sentrum \\ 0107 Oslo \\ og \\ Institutt for helse og samfunn \\ Det medisinske fakultet \\ Universitetet i Oslo \\ Berit Bringedal \\ Kari Ronge \\ Legeforeningens forskningsinstitutt
}

Legene føler at den profesjonelle autonomien gradvis er blitt mer begrenset siden midten av forrige århundre (1-3). Den tradisjonelle oppfatningen av profesjonens rolle var at utøverne selv definerte sin kompetanse, hvem som skulle være med i profesjonslauget, regler for arbeidsdeling og spesialisering, og ikke minst hvilke regler som skulle gjelde for selve profesjonsutøvelsen (4). Selvdisiplinering var derfor en viktig del av virksomheten. Den var basert på at kollegiet selv tok ansvar for de medlemmene som etisk eller faglig ikke levde opp til den standarden som ble krevd, eller som på andre måter utgjorde en antatt trussel mot pasientsikkerheten. Det er blitt hevdet at profesjonene tidvis sviktet sine idealer ved å ta mer hensyn til egne medlemmer enn til pasientenes sikkerhet (5). Samfunnet reagerte med å opprette kontroll- og tilsynssystemer som var uavhengige av profesjonenes egne organisasjoner. Disse skulle være et nødvendig ledd i den generelle kvalitetsutviklingen i helsevesenet, med økt vektlegging av pasientsikkerhet og rettighetsbasert pasientmedvirkning. Profesjonenes spesialkunnskap ble etter hvert felleseie og den enkelte profesjonsutøver en ressurs som ble eid og styrt av samfunnet gjennom de folkevalgte (6).

I 1927 ble automatisk praksisrett for medisinstudenter i Norge avløst av statsautorisasjon (7). Formålet var «å sikre legene befolkningens tillit ved å utestenge «uskikkete» yrkesutøvere» (8). Aldersgrensen på 75 år for legeautorisasjon kom med legeloven av 1980 (9), og må ses som ett av flere tiltak fra samfunnets side for å kontrollere legene og sikre pasientene best mulig behandling. Bestemmelsen ble videreført i helsepersonelloven av 1999 (10). Forholdet mellom autorisasjon og lisens er slik at selv om autorisasjonen som lege etter loven opphører ved fylte 75 år, kan legen fremdeles bruke tittelen lege og etter søknad få lisens til å drive avgrenset legevirksomhet, f.eks. med begrenset forskrivningsrett av legemidler eller begrensning til en bestemt stilling (11).

Sosialdepartementets opprinnelige begrunnelse for bestemmelsen var at «... erfaring viser at en særlig kontroll er på sin plass for de eldste årsklasser for å unngå risiko for alvorlige feil til skade både for pasienten og legen selv». Departementet foreslo imidlertid ikke noen konkret aldersgrense, dette kom forst ved behandlingen i sosialkomiteen (12).

Flertallet i komiteen foreslo en generell aldersgrense for autorisasjon på 75 år, med mulighet for fortsatt lisens etter nærmere individuell vurdering. Mindretallet mente at innføring av en slik fast aldersgrense kunne føre til at mange leger som ellers kunne være et verdifullt supplement til legetjenesten i et område, ville unnlate å søke om fortsatt tidsbegrenset lisens. Flertallets forslag ble vedtatt av Stortinget.

Reglene for forlengelse av lisensen utover 75 år er formulert i en egen forskrift (13). Det åpnes for at lisens kan gis etter søknad for to år av gangen, og etter fylte 80 år for inntil ett år av gangen. Det ble opprinnelig presisert at «virksomheten bør ikke være mindre enn tilsvarende $20 \%$ stilling», men dette møtte motstand i sosialkomiteen (14). Stortingsflertallet stemte i 2004 for et forslag om at lisensen kunne innvilges «etter en konkret og skjønnsmessig vurdering av fylkeslegen uten absolutte krav til virksomhetens art og at omfanget av virksomheten må overstige en bestemt stillingsstørrelse» (15).

Denne artikkelen er basert på spørreundersøkelser til yrkesaktive og pensjonerte leger for å kartlegge deres syn på bestemmelsen og å anslå hvor mange leger over 75 år som har søkt om og eventuelt fătt fornyet sin lisens.

\section{Materiale og metode}

Legeforeningens forskningsinstitutt har opprettet et pensjonistpanel som omfatter

\section{Hovedbudskap}

- Flertallet av yrkesaktive leger aksepterer bestemmelsen om at autoriasjonen automatisk opphører ved 75 års alder

- Hver fjerde lege i utvalget over 74 år har søkt om og fått forlenget lisens

- De viktigste grunnene til at leger over 74 år ikke søker om forlenget lisens er at de ikke ønsker det eller ikke er i aktivitet som lege 
900 legepensjonister. Utgangspunktet var samtlige 1640 leger som var registrert som alderspensjonister i Legeregisteret høsten 2006. Våren 2007 ble disse invitert til å delta $i$ et fast panel, og høsten 2007 ble et spørreskjema sendt til de 900 pensjonistene som hadde samtykket i å delta i panelet. I tillegg benytter vi data fra vårt ordinære referansepanel som består av et representativt utvalg på 1400 yrkesaktive leger som får spørreskjema annethvert år. I 2006 fikk disse legene også spørsmål om aldersbestemmelsene i forhold til autorisasjon og lisens.

Følgende spørsmål ble stilt til både yrkesaktive og pensjonerte leger: Hva mener du om at leger over 75 år må fornye sin lisens? Svaralternativene var:

1) Jeg er enig i bestemmelsen

2) Jeg er enig i prinsippet, men aldersgrensen bør være år

3) Jeg mener at den pensjonerte legen selv må bestemme når hun/han vil levere inn sin lisens

4) Jeg mener at legelisensen bør være livsvarig, uansett legens alder og helse

5) Annet, skriv:

I spørreskjemaet til de pensjonerte legene ble det dessuten spurt om hvem som fortsatt hadde lisens, hvor mange ganger man eventuelt hadde søkt om fornyet lisens samt om mulige årsaker til at man ikke hadde søkt om fornyet lisens.

Spørreskjemadata presenteres med frekvens- og krysstabeller samt grafikk.

\section{Resultater}

Spørreundersøkelsene

Det kom inn utfylte svar fra $92 \%(829 / 900)$

av legepensjonistene og 69\% (969/1 400) av de yrkesaktive legene. Begge utvalgene ble purret én gang. Gjennomsnittsalderen (SD) for legepensjonistene var 75,4 $(5,9)$ år, og for de yrkesaktive 51,8 $(9,7)$ år. 772 $(80 \%)$ av de yrkesaktive legene var enige i bestemmelsen om at leger over 75 år må fornye sin lisens, mot $284(34 \%)$ av de pensjonerte. Figur 1 viser fordelingen av svaralternativene $\mathrm{i}$ begge utvalgene samlet, gruppert etter alder. Fra 55 års alder er det en økende andel som mener at legen bør bestemme dette spørsmålet selv. I de eldste aldersgruppene ( 75 år og eldre) mener flertallet enten at lisensen bør være livsvarig eller at legen selv skal bestemme.

\section{Alternative aldersgrenser}

$94(9,7 \%)$ av de yrkesaktive og $128(15,4 \%)$ av de pensjonerte legene var enig i prinsippet om aldersgrense, men mente at aldersgrensen burde være en annen enn 75 år. Blant de 85 yrkesaktive legene som anga hva aldersgrensen eventuelt burde være, svarte 4380 år, mens 28 svarte 70 år. De resterende 14 foreslo andre aldersgrenser. Blant de 128 legepensjonistene som mente at det burde være en annen aldersgrense, var det 122 som anga en alternativ aldersgrense. 105 mente at den burde være 80 år og åtte at den burde være 85 år. De resterende ni anga andre aldersgrenser mellom 70 og 90 år.

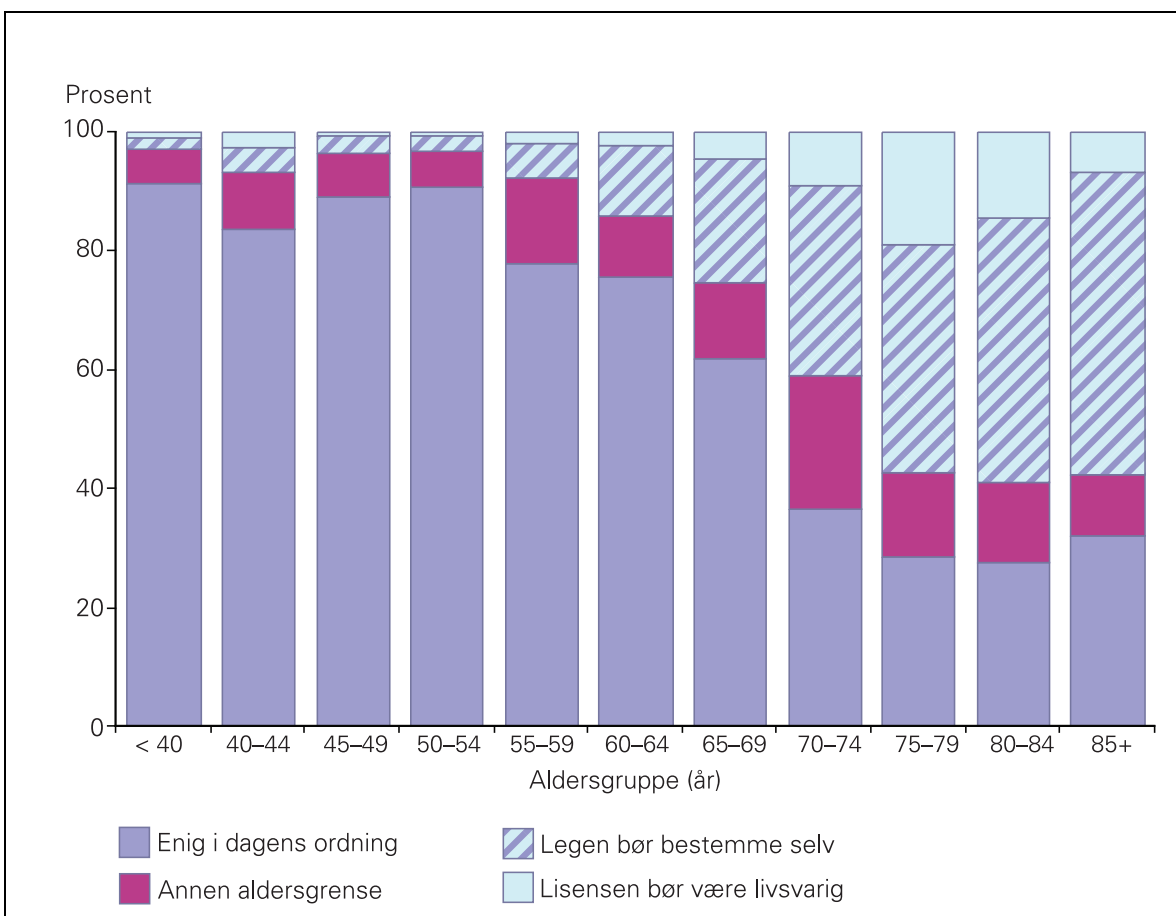

Figur 1 Svar på spørsmålet «Hva mener du om at leger over 75 år må fornye sin lisens?» i et kombinert utvalg ( $n=1751)$ av yrkesaktive ( $n=941)$ og pensjonerte $(n=810)$ norske leger. Prosentsøyler innen hver aldersgruppe. 19 pensjonister og 28 yrkesaktive leger som anga «annet» som svaralternativ er ikke inkludert

Søknad om lisens etter 75 års alder

Det var 389 leger som var 75 år eller eldre i pensjonistutvalget. Dersom vi antar at de respondentene som ikke svarte på spørsmålet om de hadde lisens, heller ikke hadde lisens, var det $25 \%(97 / 389)$ av legene over 74 år som hadde lisens. Aldersfordelingen fremgår av tabell $1.49 \%(191 / 389)$ av respondentene hadde søkt om fornyet lisens minst én gang. Antall søknader per lege på 75 år eller eldre fordelte seg som vist i tabell 2. Tabellen inkluderer også leger som ikke lenger har lisens og leger som har fått avslag.

213 legepensjonister svarte på spørsmålet om hvilke årsaker de eventuelt hadde til ikke å søke om forlenget lisens. Svarene er gjengitt i tabell 3. Blant de 72 som svarte «Annet», hadde de fleste skrevet kommentarer. Seks hadde fremdeles autorisasjon i Sverige, Finland eller Danmark, ti erklærte at de syntes de var for gamle, og noen av disse hadde hatt lisens også etter 75 år. Noen få anga at de syntes det var så nedverdigende å søke at de av den grunn ikke gjorde det. Fire med helseproblemer hadde henvendt seg til Statens autorisasjonskontor for helsepersonell (SAFH) og fått bekreftet at de sannsynligvis ikke ville få lisens av den grunn. Den største gruppen (21 leger) var de som ikke søkte fordi de mente de ikke ville tilfredsstille kravet om «organisert pasientrettet virksomhet av et visst omfang» (15).

\section{Diskusjon}

Blant de pensjonerte legene som er 75 år og eldre er bare ca. en tredel enig i bestemmelsen om aldersgrense. Det er ikke mulig ut fra våre data å tallfeste hvor mange i denne aldersgruppen som søker om fornyet lisens og får avslag. Statens autorisasjonskontor for helsepersonell opplyser imidlertid at det $i$ årene 2005-08 var til sammen 385 leger over 74 år som søkte om fornyet lisens, hvorav 371 (96\%) ble innvilget (Per Haugum, SAFH, personlig meddelelse). Det betyr at det store flertallet av søkere får forlenget sin lisens. Ifølge autorisasjonskontoret utgjør ikke arbeidet med å vurdere forlenget lisens til leger over 74 år en spesielt stor belastning på deres samlede ressurser. Blant de yngste pensjonistene, de i gruppen 70-74 år, er det $37 \%$ (112/ 305) som er enig i aldersbestemmelsen.

\section{Er alder et godt kriterium?}

På grunn av stor individuell variasjon i personlighet og ferdigheter blant leger er det neppe mulig på vitenskapelig grunnlag å definere en "sikker aldersgrense» for profesjonsutøvelsen. I en norsk undersøkelse blant yrkesaktive leger så man på hvem som hadde vært involvert $\mathrm{i}$ alvorlig pasientskade; livstidsprevalensen var faktisk lavere hos de eldste enn de middelaldrende, vel å merke basert på egenrapportering (16). I en amerikansk undersøkelse av i hvilken grad det var mulig å identifisere leger med økt risiko for feilbehandling, basert på registerdata fra 8000 leger, fant man en viss positiv sam- 
menheng mellom alder og risiko, men den flatet ut ved 50 års alder (17).

I tillegg til Norge er det kun Danmark som har en aldersgrense for autorisasjon. I 2007 vedtok det danske Folketinget en lov som bestemmer at leger, tannleger og kiropraktorer ikke får drive «selvstændigt virke» etter fylte 75 år, men at «læger vil efter fyldte 75 år fortsat kunne udskrive recepter til seg selv og nærmeste pårørende, hvis dette ikke skjer $\mathrm{i}$ erhvervsmessig øjemed». Her avviker altså de danske bestemmelsene fra de norske, som ikke åpner for forskrivningsrett til en selv og de nærmeste pårørende.

I Sverige er autorisasjonen livslang, men lisensnummeret endres når legen blir pensjonist, noe som antagelig gjør det lettere å overvåke for eksempel medikamentforskrivning. I noen land, eksempelvis i Canada (18) og Storbritannia (19), gjennomføres regelmessige vurderinger av alle legers egnethet og kompetanse, uavhengig av alder.

\section{Legeforeningens vurderinger}

I høringssvaret til forslaget om ny legelov, datert 19.8. 1976, hadde Legeforeningen ingen kommentarer til at høy alder var listet som en av mange grunner til at en lege eventuelt skulle være uskikket til å utøve legeyrket. I et tillegg til høringsnotatet til sosialkomiteens innstilling berørte Legeforeningen så vidt aldersgrenseforslaget. Foreningen skriver at formuleringen «vanligvis er aldersgrensen i Norge 70 år og generelt sett bør ikke legene ha noe privilegium i så måte» er forbausende, i og med at det ikke dreier seg om retten til å beholde en stilling, men om retten til å kunne utføre et arbeid som en er utdannet for.

Senere er Legeforeningen blitt mer kritisk til bestemmelsen. I en høringsuttalelse i 2009 sier foreningen seg uenig i departementets forslag om å gi full forskrivningsrett kun til leger over 75 år som kunne dokumentere organisert, pasientrettet virksomhet. Det sentrale kriteriet burde være skikkethet for alle leger, og ikke praksisens omfang eller en aldersgrense. I den gjeldende forskriften (15) står det i $\S 8$ : «Ved tildeling av lisens, skal søkerens egnethet vurderes i forhold til art og omfang av den virksomheten det er søkt om lisens for. Det skal legges stor vekt på hvordan helsepersonellet har holdt og vil holde seg faglig oppdatert. For dem det gjelder, kan lisens for å drive organisert pasientrettet virksomhet av et visst omfang, gis med full forskrivningsrett. Lisens for å drive pasientrettet virksomhet som ikke omfattes av første punktum, kan gis uten forskrivningsrett for A og B-preparater. Lisens for å drive pasientrettet virksomhet som kun omfatter familie, venner og andre nærstående, samt lisens som ikke skal benyttes til pasientrettet virksomhet, gis uten forskrivningsrett.»

Eldre lægers forenings rolle

Eldre lægers forening (Elf) har hatt spørsmålet om aldersgrense for autorisasjon og

Tabell 1 Lisens blant leger 75 år eller eldre i Pensjonistpanelet $(n=389)$. Antall (\%) i hver alderskategori

\begin{tabular}{|c|c|c|c|}
\hline Aldersgruppe & Har lisens & $\begin{array}{l}\text { Har ikke lisens/svarte ikke } \\
\text { på spørsmål om lisens }\end{array}$ & Alle \\
\hline $75-79$ & $67(36)$ & $118(64)$ & 185 \\
\hline $80-84$ & 25 (18) & $113(82)$ & 138 \\
\hline $85-89$ & $3(6)$ & 45 (94) & 48 \\
\hline $90+$ & $2(11)$ & 16 (89) & 18 \\
\hline Alle & 97 (25) & $292(75)$ & 389 \\
\hline
\end{tabular}

lisens som kjernesak helt siden stiftelsen i 1988. I et brev til Legeforeningens president datert 27.2. 1996 foreslo Elf-representantene Jørgen H. Berner og Fredrik Mellbye at det burde gjøres en juridisk vurdering på bakgrunn av «aktuelle lovbestemmelsers forhold til internasjonale konvensjoner om forbud mot diskriminering på grunnlag av alder alene», og de mente at saken deretter burde tas opp i sentralstyret.

Tidligere formann i Eldre lægers forening, Bjarne Waaler, karakteriserte $\mathrm{i}$ et notat til Legeforeningens sentralstyre i mars 2008 aldersbestemmelsen som «en løsning på et problem som ikke eksisterer». Notatet var et vedlegg til et brev fra Eldre lægers forening til Legeforeningens sekretariat der det bl.a. heter: «Det ville være ønskelig med en lovendring som fjerner opplevelsen av aldersdiskriminering. [...] Styret i Elf [er] enige om at vi for øyeblikket legger lovendringssaken til side og prøver å få endret forskriftene på punkter som er spesielt viktige for leger over 75 år.»

Sentralstyret drøftet henvendelsen, sendte deretter et brev til Helse- og omsorgsdepartementet og ba om vurdering av eventuell endring i lov og forskrift på bakgrunn av nye argumenter. Ikke minst fremholdt foreningen at befolkningen lever stadig lenger og blir stadig friskere, samtidig med at det er et uttalt ønske fra myndighetenes side at tiden man er yrkesaktiv skal utvides. I sitt svar, datert 23.4. 2009, avviste departementet et slikt behov og skrev: «Etter departementets vurdering ivaretar forskriften på en god måte pasientenes sikkerhet, kvalitet på helsehjelpen og den generelle tillit til helsetjenesten.»

\section{Profesjonell autonomi}

og samfunnsmessig kontroll

Når vi sammenlikner den første legeloven fra 1927 med den der man innførte aldersgrense for autorisasjon i 1980, ser vi en interessant holdningsendring. I 1927 var lovens hensikt å beskytte legene mot andre ikke-profesjonelle yrkesutøvere, slik at tilliten $\mathrm{i}$ befolkningen ikke skulle svekkes. I 1980 var det derimot pasientene som skulle beskyttes mot uskikkede leger. Dette er selvsagt et uttrykk for det moderne samfunnets økende behov for styring av profesjonene. Både helsevesenet og utdanningsinstitusjonene er gjenstand for stadig mer politisk og administrativ styring. Professoren, læreren og legen har mindre innflytelse på organiseringen av sin egen profesjonsutøvelse enn før. Denne utviklingen skyldes behovet for å sikre kvalitet og redusere kostnader, men den signaliserer også en økende mistro til profesjonenes evne til egenkontroll. Utviklingen er både positiv og negativ. Det er slutt på den tiden da laugene uten innsyn hadde mulighet til å beskytte sine egne privilegier på bekostning av andre. Samtidig representerer utviklingen en fare for at profesjonell

Tabell 2 Antall ganger 389 legepensjonister på 75 år eller eldre har søkt om lisens. Tabellen omfatter også leger som ikke lenger har lisens, eller som har fått avslag på søknad

\begin{tabular}{|crr|}
\hline Antall ganger & Antall leger & Prosent \\
\hline 0 & 198 & 50,9 \\
\hline 1 & 92 & 23,7 \\
\hline 2 & 58 & 14,9 \\
\hline 3 & 26 & 6,7 \\
\hline 4 & 5 & 1,3 \\
\hline 5 & 5 & 1,3 \\
\hline 6 & 1 & 0,3 \\
\hline 7 & 2 & 0,5 \\
\hline 9 & 1 & 0,3 \\
\hline 10 & 1 & 0,3 \\
\hline Til sammen & 389 & 100,0 \\
\hline
\end{tabular}

Tabell 3 Årsaker til at $213^{1}$ av 389 leger på 75 år eller eldre ikke søkte om fornyet lisens

\begin{tabular}{lrr} 
Årsak til ikke å søke & Antall & Prosent \\
Onsker ikke å søke & 69 & 32,4 \\
Har søkt og fått avslag & 15 & 7,0 \\
$\begin{array}{l}\text { Andre jeg kjenner } \\
\text { har fått avslag }\end{array}$ & 14 & 6,6 \\
\hline Tung saksgang & 33 & 15,5 \\
\hline Betaling & 5 & 2,3 \\
\hline $\begin{array}{l}\text { Andre negative sider } \\
\text { ved søknadsprosessen }\end{array}$ & 5 & 2,3 \\
Annet & 72 & 33,8 \\
\hline Til sammen & 213 & 100,0
\end{tabular}

De som svarte på oppfølgingsspørsmålet 
kunnskap og kompetanse blir overkjørt av byråkrati og markedskrefter (20-22).

Hvordan avveiningen bør være mellom regulering og kontroll på den ene side og faglig innflytelse og profesjonelt skjønn på den annen, blir derfor et sentralt spørsmål. Dersom utviklingen går i retning av økt kontroll med alle legers og andre profesjoners yrkesutøvelse, vil det også åpne for å utvikle mer spesifikke systemer for kontroll og tilsyn. Innholdet i og omfanget av kontroll- og tilsynstiltak vil avgjøre om et slikt system vil fungere bedre og smidigere enn dagens ordning. Det burde med andre ord gjøres en kostnad-nytte-analyse der aldersgrense som eksklusjonskriterium for autorisasjon sammenliknes med mer generelle systemer for kontroll av og tilsyn med variabler som er uavhengige av alder.

Vi takker Bjarne Waalert, Ingrid Lycke Ellingsen og Ansgar Torvik for god hjelp i forbindelse med utarbeiding av spørsmålene til pensjonistpanelet, Rolf Schøyen for hjelp til å dokumentere Eldre lægers forenings rolle, Ingrid Lycke Ellingsen for viktige innspill til artikkelutkast, Peter Psarologos for innhenting av informasjon om aldersbestemmelser i forskjellige land og yrkesgrupper samt Per Haugum og hans medarbeidere i Statens autorisasjonskontor for helsepersonell for nyttige opplysninger og synspunkter.

\section{Oppgitte interessekonflikter: Ingen}

\section{Litteratur}

1. Le Fanu J. The rise and fall of modern medicine. London: Little Brown, 1999.

2. McKinlay JB, Marceau LD. The end of the golden age of doctoring. Int J Health Serv 2002; 32: 379-416.

3. Moran M, Wood B. States, regulation and the medical profession. Buckingham, Philadelphia, PA: Open University Press, 1993

4. Abbott A. The system of professions. An essay on the division of expert labor. Chicago, Il: The University of Chicago Press, 1988

5. Freidson E. Profession of medicine. A study of the sociology of applied knowledge. Chicago, II: The University of Chicago Press, 1988.

6. Focault M. Forelesninger om regjering og styringskunst. Oslo: Cappelen Akademisk, 2002.

7. Lov av 29. april 1927 om lægers rettigheter og plikter.

8. Haave P. Da legene skulle autoriseres. Tidsskr Nor Lægeforen 2007: 127: 3267 -71.

9. Lov av 13. juni 1980 om leger.

10. Lov av 2. juli 1999 nr. 64 om helsepersonell mv.
11. Befring AK, Grytten NJ, Ohnstad B. Jus for leger. Oslo: Høyskoleforlaget, 2002: 74-6.

12. Innst. 0. nr. 55 (1979-80).

13. FOR-2000-12-21 nr. 1379. Forskrift om lisens til helsepersonell.

14. Innst. S. nr. 76 (2002-2003)

15. FOR-2004-08-30 nr. 1224. Forskrift om endring i forskrift om lisens for helsepersonell.

16. Aasland OG, Førde R. Impact of feeling responsible for adverse events on doctors' personal and professional lives: the importance of being open to criticism from colleagues. Qual Saf Health Care 2005; 14: 13-7.

17. Rolph JE, Adams JL, Kimberly A. Identifying malpractice-prone physicians. J Empir Leg Stud 2007; 4: $125-53$.

18. Collier R. Diagnosing the aging physician. CMAJ 2008; 178: 1121-3.

19. General Medical Council. Revalidation. www. gmc-uk.org/doctors/licensing.asp (30.3.2010).

20. Power M. The Audit Society. Rituals of verification Oxford: Oxford University Press, 1999.

21. Rose N. Miller P. Political power beyond the state. Problematics of government. 1992. Br J Sociol 2010; 61 (suppl 1): 271-303.

22. Freidson E. Professionalism - the third logic. Cambridge/Oxford: Polity Press/Blackwell Publishers, 2001.

Manuskriptet ble mottatt 21.9. 2009 og godkjent 1.7. 2010. Medisinsk redaktør Mette Sagsveen. 